\title{
Histone deacetylase inhibitors (HDACls): multitargeted anticancer agents
}

This article was published in the following Dove Press journal:

Biologics:Targets and Therapy

23 February 2013

Number of times this article has been viewed

\section{Katherine Ververis' \\ Alison Hiong' \\ Tom C Karagiannis $1, *$ \\ Paul V Licciardi ${ }^{2}$,*}

'Epigenomic Medicine, Alfred Medical Research and Education Precinct,

${ }^{2}$ Allergy and Immune Disorders,

Murdoch Childrens Research Institute,

Melbourne, VIC, Australia

*These authors contributed equally to this work

Video abstract

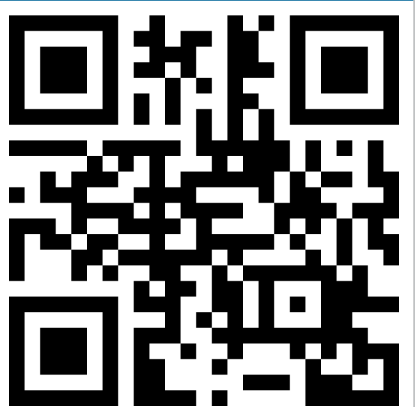

Point your SmartPhone at the code above. If you have a QR code reader the video abstract will appear. Or use: http://dvpr.es/VOuUng
Correspondence: Paul V Licciardi Allergy and Immune Disorders Group, Murdoch Childrens Research Institute, Melbourne, VIC 3052, Australia Email paul.licciardi@mcri.edu.au
Abstract: Histone deacetylase (HDAC) inhibitors are an emerging class of therapeutics with potential as anticancer drugs. The rationale for developing HDAC inhibitors (and other chromatin-modifying agents) as anticancer therapies arose from the understanding that in addition to genetic mutations, epigenetic changes such as dysregulation of HDAC enzymes can alter phenotype and gene expression, disturb homeostasis, and contribute to neoplastic growth. The family of HDAC inhibitors is large and diverse. It includes a range of naturally occurring and synthetic compounds that differ in terms of structure, function, and specificity. HDAC inhibitors have multiple cell type-specific effects in vitro and in vivo, such as growth arrest, cell differentiation, and apoptosis in malignant cells. HDAC inhibitors have the potential to be used as monotherapies or in combination with other anticancer therapies. Currently, there are two HDAC inhibitors that have received approval from the US FDA for the treatment of cutaneous T-cell lymphoma: vorinostat (suberoylanilide hydroxamic acid, Zolinza) and depsipeptide (romidepsin, Istodax). More recently, depsipeptide has also gained FDA approval for the treatment of peripheral T-cell lymphoma. Many more clinical trials assessing the effects of various HDAC inhibitors on hematological and solid malignancies are currently being conducted. Despite the proven anticancer effects of particular HDAC inhibitors against certain cancers, many aspects of HDAC enzymes and HDAC inhibitors are still not fully understood. Increasing our understanding of the effects of HDAC inhibitors, their targets and mechanisms of action will be critical for the advancement of these drugs, especially to facilitate the rational design of HDAC inhibitors that are effective as antineoplastic agents. This review will discuss the use of HDAC inhibitors as multitargeted therapies for malignancy. Further, we outline the pharmacology and mechanisms of action of HDAC inhibitors while discussing the safety and efficacy of these compounds in clinical studies to date.

Keywords: chromatin modifications, histone acetylation, histone deacetylase inhibitor, suberoylanilide hydroxamic acid, depsipeptide, entinostat

\section{Introduction}

Within eukaryotic cells, chromatin architecture consists of tightly packed DNA, histones, and nonhistone proteins. ${ }^{1}$ The basic organizing unit of chromatin is the nucleosome and comprises a histone octamer core containing two units each of H2A, H2B, H3, and H4, with 147 base pairs of DNA wrapped tightly around the protein core 1.65 times. ${ }^{1,2}$ This allows for highly dynamic chromatin architecture. Chromatin undergoes a continual process of condensation and decondensation, which regulates the access of the cellular machinery to specific DNA sequences to facilitate metabolic processes, including transcription, replication, and repair. ${ }^{3,4}$ The amino acid 
N-terminal tails of each of the core histones are substrates for a variety of enzyme-catalyzed, reversible, posttranslational modifications, including acetylation, phosphorylation, methylation, and ubiquitination. The combined effect of these modifications creates an epigenetic marking system, or a "histone code," which governs gene expression. ${ }^{5}$

Of the various posttranslational modifications, histone acetylation is relatively well characterized. The acetylation status of histones is controlled by the opposing actions of two classes of enzymes: histone acetyltransferases (HATs), which transfer acetyl groups to lysine residues within the N-terminal tails of core histones, and histone deacetylases (HDACs), which remove the acetyl groups. ${ }^{6,7}$ The acetylation status of histones influences chromatin conformation and affects the accessibility of transcription factors and effector proteins to the DNA, thereby modifying gene expression. ${ }^{7}$

There are two well-characterized mechanisms by which histone acetylation increases transcriptional activity. ${ }^{4}$ Firstly, the transfer of the acetyl moiety of acetyl coenzyme A by HATs results in the acetylation of the $\varepsilon$-amino tails of lysine residue in histones. ${ }^{8}$ This neutralizes the positive charge of the histone tails and reduces the affinity of histones for the negatively charged DNA backbone, thereby loosening the structure of the chromatin. ${ }^{6,8}$ This enables the transcriptional machinery to access the DNA and enhances gene transcription. ${ }^{4}$ Conversely, HDACs remove the acetyl group from the histone tails, reversing the effects of HATs and altering transcription. ${ }^{9}$ Secondly, histone acetylation mediates the recruitment of nonhistone proteins to the DNA. Modification of histone tails creates sites that are recognized by effector proteins, which have bromodomains that specifically interact with the modified residues. ${ }^{10,11}$ Subsequently, the recruited effector proteins modulate DNA transcription. ${ }^{11}$ It has been widely accepted that enhanced histone acetylation is associated with transcriptionally active DNA, whereas hypoacetylation of histones is associated with transcriptional repression. ${ }^{4,7}$ However, recent findings have indicated that histone hyperacetylation may not necessarily translate to increased gene expression alone, but also has effects on gene repression or inactivation. ${ }^{12,13}$

There are currently 18 mammalian HDAC enzymes that have been identified (Table 1). These enzymes are classified into four main classes, based on their homology to yeast. ${ }^{14,15}$ The "classical," metal-dependent HDAC enzymes involve class I, II, and IV HDACs and the sirtuins; the nonmetal-dependent enzymes represent class III. ${ }^{16}$ The sirtuins (1-7) share homology to the yeast silent information regulator 2 and differ from the classical HDAC enzymes,
Table I Classification of the eleven metal-dependent histone deacetylase (HDAC) enzymes

\begin{tabular}{|c|c|c|c|}
\hline HDAC enzyme & $\begin{array}{l}\text { Size (amino } \\
\text { acid) }\end{array}$ & $\begin{array}{l}\text { Chromosomal } \\
\text { size }\end{array}$ & Localization \\
\hline \multicolumn{4}{|l|}{ Class I (Rpd3) } \\
\hline $\mathrm{HDACl}$ & 482 & Ip34.| & Nucleus \\
\hline HDAC2 & 488 & $6 q 21$ & Nucleus \\
\hline HDAC3 & 428 & $5 q 31.3$ & Nucleus \\
\hline HDAC8 & 377 & $X q 13$ & Nucleus/cytoplasm \\
\hline \multicolumn{4}{|l|}{ Class Ila (Hda I) } \\
\hline HDAC4 & 1084 & $2 q 37.2$ & Nucleus/cytoplasm \\
\hline HDAC5 & 1122 & $|7 q 2|$ & Nucleus/cytoplasm \\
\hline HDAC7 & 912 & $12 q 13.1$ & Nucleus/cytoplasm \\
\hline HDAC9 & 1069 & $7 p \mid 2.1$ & Nucleus/cytoplasm \\
\hline \multicolumn{4}{|l|}{ Class Ilb (Hda I) } \\
\hline HDAC6 & 1215 & XpII.22 & Cytoplasm \\
\hline HDACIO & 669 & $22 q \mid 3.3$ & Cytoplasm \\
\hline \multicolumn{4}{|c|}{ Class IV (Rpd3/Hdal) } \\
\hline HDACII & 347 & $3 p 25.2$ & Nucleus/cytoplasm \\
\hline
\end{tabular}

as they require the consumption of nicotinamide adenine dinucleotide to deacetylate the lysine residues. The sirtuins have been associated with cell proliferation and cellcycle control. ${ }^{17}$ The classical HDAC enzymes are metaldependent as they contain zinc catalytic binding domains. ${ }^{15}$ Class I enzymes contain HDAC1, $-2,-3$, and -8 and are expressed ubiquitously and share homology with the yeast transcriptional regulator RDP3. ${ }^{16}$ These isotypes are usually expressed within the nucleus and act as transcriptional corepressors. The class II enzymes share homology with the yeast HDAC1 and are subdivided into class IIa, consisting of HDAC4, -5, -7, and -9, and class IIb, containing HDAC6 and $-10 .{ }^{18}$ These isotypes show tissue-specific distribution and are known to shuttle between the nucleus and cytoplasm, although histone proteins broadly represent their main target. The class IIb enzymes differ in that they primarily localize to the cytoplasm and differ structurally by containing two catalytic sites. ${ }^{19}$ HDAC11 shares homology with the class I isotypes, but shows more tissue-specific distribution with cytoplasmic localization. As it shares relationships with both class I and class II HDACs and structural homology to yeast, it has been designated a distinct class IV. ${ }^{15}$

Although HDACs cause the deacetylation of histones, phylogenetic studies indicate that histones are not the primary substrates for HDACs. ${ }^{15}$ In fact, HATs and HDACs can also regulate gene expression indirectly by mediating the posttranslational acetylation and deacetylation of various nonhistone protein substrates. ${ }^{20}$ HDACs have more than 50 nonhistone protein substrates, such as DNA-binding proteins, transcription factors, signal-transduction molecules, DNA-repair proteins, and chaperone proteins. ${ }^{20,21}$ (Table 2). 
Table 2 Partial list of nonhistone protein substrates of HDACs

\begin{tabular}{|c|c|c|c|c|}
\hline Effect of acetylation & Protein & Intracellular function & HDAC implicated & References \\
\hline Increased DNA-binding & p53 & Tumor suppressor & & 129 \\
\hline \multirow[t]{6}{*}{ affinity } & SRY & Transcription factor & HDAC3 & 130 \\
\hline & STAT3 & Signaling mediator & HDACI, $-2,-3$ & $|3|$ \\
\hline & GATAI & Transcription factor & HDAC3, $-4,-5$ & 132 \\
\hline & GATA2 & Transcription factor & HDAC3, -5 & 133 \\
\hline & E2FI & Transcription factor & $\mathrm{HDACl}$ & 134 \\
\hline & MyoD & Transcription factor & HDACI & 135 \\
\hline Decreased DNA-binding & YYI & Transcription factor & $\mathrm{HDACl},-2,-3$ & 136 \\
\hline \multirow[t]{3}{*}{ affinity } & HMG-AI & Nuclear factor & & 137 \\
\hline & HMG-N2 & Nuclear factor & & 138 \\
\hline & p65 & Transcription factor & & 139 \\
\hline Increased transcriptional & $\mathrm{p} 53$ & Tumor suppressor & & 129,140 \\
\hline \multirow[t]{11}{*}{ activation } & HMG-AI & Nuclear factor & & $|4|$ \\
\hline & STAT3 & Signaling mediator & $\mathrm{HDACl},-2,-3$ & $|3|, \mid 42$ \\
\hline & $A R$ & Nuclear receptor & $\mathrm{HDACl}$ & 143,144 \\
\hline & $\mathrm{ER} \alpha$ (basal) & Steroid hormone receptors & $\mathrm{HDACl}$ & 145 \\
\hline & GATAI & Transcription factor & HDAC3, $-4,-5$ & 132 \\
\hline & GATA2 & Transcription factor & $\mathrm{HDAC} 3,-5$ & 133 \\
\hline & GATA3 & Transcription factor & & 146 \\
\hline & EKLF & Transcription factor & $\mathrm{HDACl}$ & 147 \\
\hline & MyoD & Transcription factor & HDACI & 135 \\
\hline & E2FI & Transcription factor & HDACI & 134,148 \\
\hline & RUNX3 & Tumor suppressor & $\mathrm{HDACl},-5$ & 149 \\
\hline Decreased transcriptional & ER $\alpha$ (ligand-dependent) & Steroid hormone receptors & $\mathrm{HDACl}$ & 145 \\
\hline activation & $\mathrm{HIFI} \alpha$ & Transcription factor & & 150 \\
\hline \multirow[t]{7}{*}{ Increased protein stability } & p53 & Tumor suppressor & HDACI & $|5|$ \\
\hline & c-MYC & Oncoprotein & & 152 \\
\hline & $A R$ & Nuclear receptor & $\mathrm{HDACl}$ & 153 \\
\hline & $\mathrm{ER} \alpha$ & Steroid hormone receptors & HDACI & 154 \\
\hline & E2FI & Transcription factor & HDACI & 134 \\
\hline & Smad7 & Signaling mediator & $\mathrm{HDACl},-3$ & 155 \\
\hline & RUNX3 & Tumor suppressor & $\mathrm{HDACl},-5$ & 149 \\
\hline Decreased protein stability & $\mathrm{HIFI} \alpha$ & Transcription factor & & 150 \\
\hline Promotes protein-protein & STAT3 & Signaling mediator & $\mathrm{HDACl},-2,-3$ & $|3|$ \\
\hline \multirow[t]{3}{*}{ interaction } & AR & Nuclear receptor & $\mathrm{HDACl}$ & 156 \\
\hline & EKLF & Transcription factor & HDACI & 157 \\
\hline & Importin $\alpha$ & Nuclear import factors & & 158 \\
\hline Disrupts protein-protein & $N F-\kappa B$ & Transcription factor & & 159 \\
\hline \multirow[t]{2}{*}{ interaction } & Ku70 & DNA-repair protein & & 160 \\
\hline & Hsp90 & Chaperone & HDAC6 & 161 \\
\hline
\end{tabular}

Abbreviations: SRY, sex-determining region Y; STAT, signal transducer and activator of transcription; GATA, GATA-binding factor; E2F, E2F transcription factor; MyoD, myogenic differentiation; YYI, transcriptional repressor protein; HMG, High Mobility Group; AR, androgen receptor; ER, estrogen receptor; EKLF, Erythroid Kruppellike factor; RUNX, Runt-related transcription factor; HIF, Hypoxia-inducible factor; NF-kB, nuclear factor kappa-B; Ku70, ATP-dependent DNA helicase; Hsp, heat-shock protein.

The posttranslational modification of these nonhistone proteins can affect many vital regulatory processes, including gene expression, mRNA stability, protein activity, and protein stability. ${ }^{22}$ For example, HDAC-mediated deacetylation of DNA-binding transcription factors affects their DNA-binding activity, which in turn alters expression of the gene.

Abnormalities in the activity or expression of HDACs and HATs can lead to an imbalance between the acetylation and deacetylation of their substrates. Given the importance of histone acetylation and deacetylation in altering chromatin architecture and regulating gene transcription, it follows that abnormalities in histone acetylation status can play a significant role in human disease. ${ }^{23,24}$ Furthermore, HDACs and HATs have many nonhistone protein substrates, and consequently, the biological implications of HDAC and HAT dysregulation can extend beyond altered gene expression. ${ }^{20}$

Irregularities in histone acetylation status have been implicated in the development and progression of many diseases, particularly cancer. In particular, loss of acetylation at Lys16 and trimethylation at Lys 20 of histone $\mathrm{H} 4$ has 
been found to be a common hallmark of human cancer. ${ }^{25}$ Furthermore, several lines of evidence have demonstrated the involvement of various HDACs in many malignancies. For example, overexpression of specific HDACs has been identified in a range of human cancers, including HDAC1 in gastric $^{26}$ and prostate ${ }^{27}$ cancer, HDAC1 and -6 in breast cancer, ${ }^{28,29}$ and HDAC2 and -3 in colorectal cancer. ${ }^{30,31}$ Furthermore, murine knockout models have given rise to possible side effects from the absence of HDACs. Experiments using HDAC1, HDAC2, HDAC3, HDAC4, or HDAC7 knockout mice showed either embryonic lethality or death soon after birth. ${ }^{32-36}$ HDAC3, HDAC5, and HDAC9 knockouts have shown severe cardiac defects involving hypertrophy and fibrosis, and HDAC8 has displayed craniofacial defects. ${ }^{34,37,38}$ In other cancers, HDAC enzymes are aberrantly recruited to gene promoters. One wellcharacterized example of aberrant HDAC recruitment in human cancer is that induced by the oncogenic PML-RAR $\alpha$ fusion protein. PML-RAR $\alpha$ causes acute promyelocytic leukemia by recruiting HDAC-containing complexes to specific target genes, which constitutively repress gene expression. ${ }^{39}$ This has led to the development of HDAC inhibitors (HDACIs) as anticancer therapies.

\section{Pharmacology, classification, and functions of histone deacetylase inhibitors}

HDACIs are a family of naturally derived and synthetically produced compounds that target the classical HDAC enzymes. They are a diverse group of compounds, which vary in structure, biological activity, and specificity. Although histone hyperacetylation is generally associated with transcriptional activation, inhibition of HDACs (which in turn favors histone hyperacetylation) does not necessarily result in a global increase in gene transcription. It has been estimated that up to $20 \%$ of all known genes are affected by HDACIs, and of these genes, about half are downregulated and half are upregulated. ${ }^{9}$

At present, two HDACIs - vorinostat (suberoylanilide hydroxamic acid, Zolinza) and depsipeptide (romidepsin, Istodax) - have received approval from the US Food and Drug Administration (FDA) for treatment of refractory cutaneous T-cell lymphoma (CTCL), and more recently, depsipeptide has gained FDA approval for peripheral T-cell lymphoma (PTCL). ${ }^{40,41}$ Developments have been made to create chemically distinct HDACIs, with several undergoing intensive clinical trials in various malignancies, many of them focusing on hematological entities, such as the leukemias, lymphomas, and myelodysplastic syndrome. ${ }^{42,43}$

Broadly, HDACIs can be classified into different structural groups (Table 3): the hydroxamic acids, cyclic peptides, bibenzimides, and short-chain fatty acids. The hydroxamates include vorinostat, givinostat, abexinostat, panobinostat, belinostat, and the prototypical HDACI trichostatin A. The cyclic peptides include compounds such as depsipeptide and trapoxin. Benzamides include entinostat and mocetinostat, and together with the hydroxamates and cyclic peptides, have relatively potent inhibition activity within the nanomolar range. Generally, the hydroxamates exert nonspecific HDAC-inhibition activity affecting all classes of HDACs. ${ }^{44,45}$ Other compounds can exert their properties specifically on class I HDACs, eg, the benzamide entinostat (MS-275), or class I and IIa HDACs, as in the case for the short-chain fatty acids valproic acid (VPA) and butyrate. ${ }^{46}$ Isotype-selective compounds are also increasingly becoming available, eg, tubacin, mocetinostat, and PC-34501 selectively inhibit HDAC6, -1 , and -8 , respectively. ${ }^{47-50}$ However, there has been much debate over whether isotype and class-specific HDACIs are preferred over broad-spectrum HDACIs.

\section{Mechanisms of HDAC inhibitors}

The cellular response to HDACIs is complex and is likely to involve transcriptional and nontranscriptional phenomena. By blocking the activity of HDAC enzymes, HDACIs promote the acetylation of histones and nonhistone proteins. HDACI-mediated modification of histones can result in increased or decreased gene expression (Figure 1). In addition, targeting histones can influence other DNAbased processes, including DNA replication and repair. Alternatively, through their actions on nonhistone proteins, such as transcription factors and heat shock proteins, HDACIs can alter transcription indirectly, or they may modulate a wide range of cellular processes other than gene expression, through nontranscriptional mechanisms. As a result of these processes, HDACIs are able to elicit a multitude of biological effects on cells, such as apoptosis, cell-cycle arrest, necrosis, autophagy, differentiation, and migration. ${ }^{19,51}$

HDACIs have been found to upregulate the cell cyclindependent kinase inhibitor p21 and subsequently block the cyclin/CDK complexes, leading to cell $\mathrm{G}_{1}$ cycle arrest in malignant cell lines. ${ }^{52,53}$ Furthermore, HDACIs cause reduced cyclin-dependent kinase activity via the downregulation of cyclins, causing $\mathrm{Rb}$ dephosphorylation and indirectly effecting E2F transcription activity. ${ }^{54}$ 
Table 3 Characteristics of histone deacetylase (HDAC) inhibitors currently undergoing clinical trials

\begin{tabular}{|c|c|c|c|c|}
\hline HDAC inhibitor & Structure & $\begin{array}{l}\text { HDAC class } \\
\text { specificity }\end{array}$ & Potency & Clinical trials \\
\hline \multicolumn{5}{|l|}{ Hydroxamic acids } \\
\hline Trichostatin A (TSA) & & I, II, IV & $\mathrm{nM}$ & - \\
\hline $\begin{array}{l}\text { Vorinostat (suberoylanilide } \\
\text { hydroxamic acid, } \\
\text { SAHA) }\end{array}$ & & I, II, IV & $\mathrm{nM}$ & $\begin{array}{l}\text { FDA-approved (2006), } \\
\text { phase II, III }\end{array}$ \\
\hline $\begin{array}{l}\text { Givinostat } \\
\text { (ITF2357) }\end{array}$ & & I, II & $\mathrm{nM}$ & Phase I, II \\
\hline $\begin{array}{l}\text { Abexinostat } \\
(\mathrm{PCl}-2478 \mathrm{I})\end{array}$ & & I, II, IV & $\mathrm{nM}$ & Phase I, II \\
\hline $\begin{array}{l}\text { Belinostat } \\
\text { (PXDIOI) }\end{array}$ & & I, II, IV & $\mu M$ & Phase I, II \\
\hline $\begin{array}{l}\text { Panobinostat } \\
(\mathrm{LBH} 589)\end{array}$ & & I, II, IV & $\mu M$ & Phase II, III \\
\hline $\begin{array}{l}\text { Resminostat } \\
(4 S C-20 I)\end{array}$ & & I, II, IV & $\mu M$ & Phase I, II \\
\hline $\begin{array}{l}\text { Quisinostat } \\
\text { (JNJ-2648I585) }\end{array}$ & & I, II, IV & $\mu M$ & Phase I \\
\hline \multicolumn{5}{|l|}{ Cyclic peptide } \\
\hline $\begin{array}{l}\text { Depsipeptide } \\
\text { (romidepsin) }\end{array}$ & & I & $\mathrm{nM}$ & $\begin{array}{l}\text { FDA-approved (2009), } \\
\text { phase I, II }\end{array}$ \\
\hline \multicolumn{5}{|l|}{ Benzamides } \\
\hline $\begin{array}{l}\text { Entinostat } \\
\text { (MS-275) }\end{array}$ & & I & $\mu M$ & Phase II \\
\hline $\begin{array}{l}\text { Mocetinostat } \\
\text { (MGCD0I03) }\end{array}$ & & $\mathrm{HDACl}$ & $\mu M$ & Phase I, II \\
\hline \multicolumn{5}{|l|}{ Fatty acids } \\
\hline Valproic acid (VPA) & & I, II & $\mathrm{mM}$ & Phase I, II, III \\
\hline Butyrate & 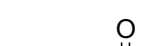 & I, II & $\mathrm{mM}$ & Phase II \\
\hline
\end{tabular}




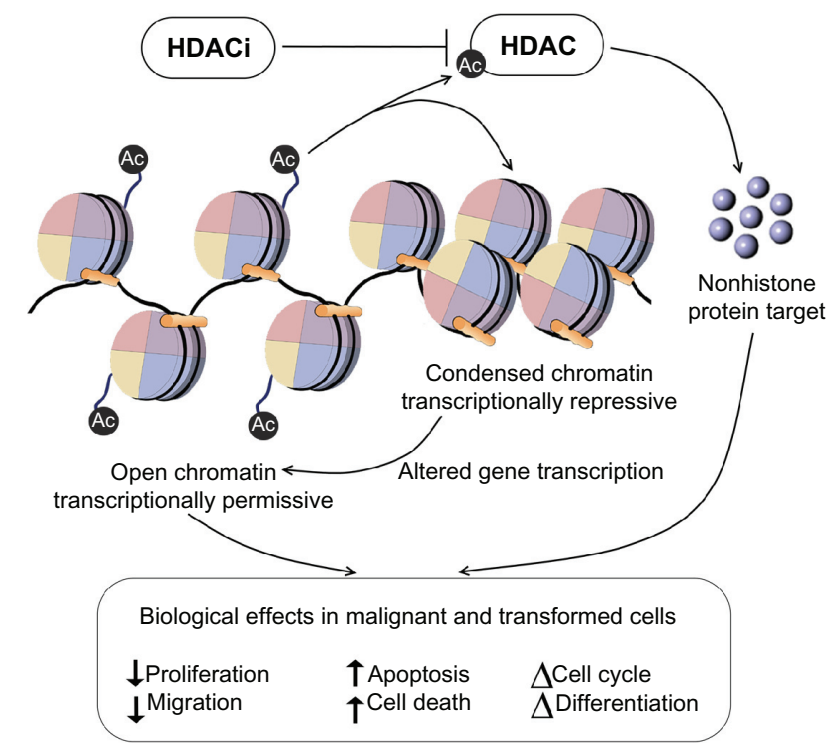

Figure I HDAC inhibitors promote the acetylation of histones and nonhistone proteins by inhibiting the activity of HDAC enzymes.

Notes: HDAC inhibitor-mediated modification of histones and nonhistone proteins (examples shown) can result in increased or decreased gene expression, influencing other DNA-based processes, including DNA replication and repair. As a result of these processes, HDAC inhibitors are able to elicit a multitude of biological effects on cells, such as apoptosis, cell-cycle arrest, and angiogenesis.

Abbreviations: HDACls, histone deacetylase inhibitors; HIF, hypoxia-inducible factor; VEGF, vascular endothelial growth factor.

Many in vitro studies have shown the combination of HDACIs with DNA-damaging agents and ionizing radiation cause DNA double-strand breaks, measured by the induction of phosphorylated histone $\mathrm{H} 2 \mathrm{AX} .{ }^{55}$ Although HDACIs may not independently induce DNA double-strand breaks, their involvement in DNA damage may be via several mechanisms. One hypothesis suggests that following alteration of chromatin structure by hyperacetylation, exposure to and severity of DNA-damaging agents is increased. ${ }^{56}$ Secondly, genes involved in both the homologous recombination and nonhomologous double-strand break-repair pathways are downregulated by HDACIs, such as Ku86, BRCA1, and RAD51..$^{57,58}$

Apoptosis, the process of programmed cell death, is mediated by intrinsic and extrinsic pathways and is important for tissue homeostasis and development. Apoptosis has been characterized by plasma membrane blebbing and DNA degradation and fractionation of the cell into small vesicles, which are engulfed by phagocytes. ${ }^{59}$ HDACIs have been shown to induce apoptosis in both solid and hematological malignancies using both transcription-dependent and transcription-independent mechanisms. ${ }^{9,60}$

HDAC inhibition meddles with the balance between pro- and antiapoptotic proteins involved in cell death. Death receptors and ligands that characterize the extrinsic apoptosis pathways are upregulated by HDACIs and TRAIL (tumor necrosis factor-related apoptosis-inducing ligand) sensitivity may be restored in TRAIL-resistant malignant cells. ${ }^{61}$ The intrinsic apoptotic pathway is characterized by mitochondrial disruption in response to stress. HDACIs downregulate prosurvival proteins such as Bcl-2 and Bcl-1, which maintain mitochondrial integrity, ${ }^{62}$ and upregulate proapoptotic proteins such as Bim, Bak, and Bax, which function as sensors of cellular stress and initiate the intrinsic pathway. ${ }^{54,63}$ Furthermore, hyperacetylation in malignant cells has shown to stabilize $\mathrm{p} 53$, promoting cell-cycle arrest and expression of proapoptotic genes. ${ }^{64}$

The ability of HDACIs to produce these effects suggests that they may be utilized as effective anticancer drugs, eg, by causing apoptosis, DNA damage, or growth arrest in malignant cells. Notably, it has been widely reported that the actions of HDACIs demonstrate relative selectivity for transformed cells over normal cells. ${ }^{65}$ Furthermore, as well as their effects on tumor cells, HDACIs may also have indirect effects on tumor growth by regulating the host immune response and the tumor vasculature. ${ }^{60}$

Angiogenesis - the formation of new blood vessels from preexisting vasculature - is driven by the release of vascular endothelial growth factor (VEGF) from surrounding endothelial progenitor cells, macrophages, and fibroblasts. ${ }^{66}$ Hypoxia-inducible factor (HIF)- $1 \alpha$ mediates the expression of several genes involved in angiogenesis and other signaling pathways via the increased expression of VEGF, which induces tumor blood-vessel formation. ${ }^{67}$ HDAC inhibition has been found to regulate HIF- $1 \alpha$ activity indirectly in hypoxic conditions by suppressing HIF-1 $\alpha$ and VEGF in malignant in vitro and in vivo models, thus blocking angiogenesis. ${ }^{68}$ Studies performed under hypoxic conditions in malignant cell lines have shown HDAC1 to be upregulated, subsequently leading to the reduced expression of p53 and von Hippel-Lindau tumor-suppressor genes, with downstream effects of increased HIF- $1 \alpha$ and VEGF expression and stimulating angiogenesis of endothelial cells. Treatments with the classical HDACI trichostatin A reversed these effects by upregulating p53 and von Hippel-Lindau tumor-suppressor genes and downregulating HIF- $1 \alpha$ and VEGF. ${ }^{68}$

Furthermore, HIF- $1 \alpha$ can also be suppressed indirectly and independently by p300 acetylation. ${ }^{69}$ Hyperacetylation of chaperone protein Hsp90 via inhibition of HDAC6 by HDACIs leads to increased affinity to HIF- $1 \alpha$. As a result, HIF-1 $\alpha$ disrupts Hsp90 chaperone function and exposes HIF- $1 \alpha$ to proteasomal degradation by Hsp $70 .{ }^{70}$ 


\section{HDAC inhibitors in clinical trials}

Currently, there are over 80 clinical trials investigating more than eleven different HDACIs for both solid and hematological malignancies as either monotherapies or in combination with various other antitumor agents.

\section{Vorinostat}

The hydroxamic acid vorinostat was FDA-approved in 2006 for CTCL, which previously could not be treated with multiple or systemic drugs. ${ }^{40} \mathrm{FDA}$ approval was based on two phase II clinical trials with a $30 \%$ response rate in patients with CTCL. Although response rates were similar to previously used therapies, vorinostat showed relatively higher relief from pruritus in comparison to other agents used in the advanced form of the disease. Vorinostat was generally well tolerated, with adverse side effects including diarrhea, fatigue, and nausea. Some patients experienced pulmonary embolism and thrombocytopenia, and there is evidence of long-term safety. ${ }^{71-73}$ Similar response rates have been observed in patients with relapsed nonHodgkin's lymphoma and mantle-cell lymphoma; however, the response rates in solid cancers has been ineffective or modest at best. ${ }^{74}$ Studies in either relapsed or refractory breast, colorectal, or non-small-cell lung cancer had no response. ${ }^{75-77}$ Vorinostat used as a single agent in patients with squamous cell carcinoma of head and neck or ovarian cancer was well tolerated and safe but ineffective..$^{78,79}$ Studies with breast cancer patients showed no response, with side effects following treatment. ${ }^{75}$ Although clinical results with Vorinostat used as a single agent have been unsuccessful in treatment of solid malignancies, preclinical data strongly suggest combination with conventional cancer therapies would be beneficial. Table 4 outlines a list of combinatorial therapies with vorinostat currently under clinical investigations.

\section{Depsipeptide}

Depsipeptide represents a bicyclic peptide that has demonstrated potent cytotoxic activity against malignant cells in both in vitro investigations and in vivo tumor xenograft models. A plethora of clinical trials have been undertaken with depsipeptide, representing phase I/II and III trials in patients with colorectal, renal, and breast neoplasms and sarcomas, as well as a wide range of hematological malignancies. Nonhematological toxicities have been mild to moderate, with no record of life-threatening or cardiac toxicities. In summary, depsipeptide can be administered with acceptable short-term toxicity; however, monotherapy appears to have limited clinical activity in acute myeloid leukemia and myelodysplastic syndrome patients. ${ }^{80-85}$

\section{Entinostat}

Entinostat (formerly known as MS-2750) has been shown to exhibit many antitumor activities in a range of preclinical investigations. Phase I clinical studies were performed in patients with relapsed or refractory acute myeloid leukemia or refractory solid tumors. Results demonstrated safety and were well tolerated up to $8 \mathrm{mg} / \mathrm{m}^{2}$. No grade 4 toxicities were observed, and dose-limiting toxicities were reversible with no long-term adverse outcomes. Common low-grade toxicities included nausea/vomiting, constipation, fatigue, and cytopenias. HDAC inhibition was observed in PBMCs, and pharmacokinetic analysis suggested a 39 to 80 -hour half-life. ${ }^{86-88}$

\section{Valproic acid}

VPA is a short-chain fatty acid that has been used in the clinic for the treatment of epilepsy for more than 30 years. Given its HDAC-inhibition activities, VPA has been extensively tested as a monotherapy, but also in combination with other anticancer modalities. In phase I clinical trials, patients with acute myeloid leukemia or myelodysplastic syndrome were treated with VPA, with improvement in $24 \%$ of patients. Patients who were either not responsive or who relapsed were also administered all-trans retinoic acid, and the response duration was halved with no additional side effects. Overall, the combination of epigenetic therapy appeared to be more successful in leukemias and was associated with a reverse of aberrant epigenetic marks. ${ }^{89}$ In separate studies, patients who had acute myeloid leukemia or high-risk myelodysplastic syndrome were administered the combination therapy of the DNA hypomethylating agent azacitidine, all-trans retinoic acid, and VPA. The study reported significant clinical activity and a safe combination..$^{90}$ Phase I clinical studies have also been performed on solid malignancies, with reports of well-tolerated toxicities. ${ }^{91-93}$ In a clinical trial to assess whether VPA can modulate the effectiveness of temozolomide radiochemotherapy in patients with glioblastoma, it was suggested the combined therapy with VPA was more effective over patients treated with an enzyme-inducing antiepileptic drug. Furthermore, patients treated with VPA had greater success over patients who were not administered any antiepileptics. This study suggests that the observed outcome of combining VPA with temozolomidebased chemoradiotherapy is due to the inhibition of HDAC by VPA. However further investigations are required 
Table 4 Partial list of current clinical trials involving histone deacetylase inhibitors as single and combination therapies

\begin{tabular}{|c|c|c|c|c|c|}
\hline Treatment & Phase & Disease & $\begin{array}{l}\text { Patient } \\
\text { number }\end{array}$ & Dose & Safety/efficacy \\
\hline \multicolumn{6}{|c|}{ Single agents } \\
\hline Vorinostat & Ila & $\begin{array}{l}\text { Myelodysplastic syndromes, } \\
\text { bone marrow disease }\end{array}$ & $\begin{array}{l}\text { A: } 10 \text { patients } \\
\text { B: } 12 \text { patients }\end{array}$ & $\begin{array}{l}\text { A: } 400 \mathrm{mg} \text { daily; } 2 \mathrm{I} \text {-day cycles } \\
\text { up to } 8 \text { cycles } \\
\text { B: } 200 \mathrm{mg} / 3 \text { per day; } 21 \text {-day cycles } \\
\text { up to } 8 \text { cycles }\end{array}$ & $\begin{array}{l}\text { Total SAEs, } 3 / 22 \text {; lack } \\
\text { of efficacy, I0/22; } \\
\text { progressive disease, } \\
\text { I/22; response rate, } 0 / 2 \text { I }\end{array}$ \\
\hline Vorinostat & II & $\begin{array}{l}\text { Relapsed or refractory } \\
\text { Hodgkin's lymphoma }\end{array}$ & 25 patients & $400 \mathrm{mg} /$ day; 14 days of 21 -day cycle & $\begin{array}{l}\text { SAEs, } 7 / 25 \text {; death, } 2 / 25 \text {; } \\
\text { lack of efficacy, I I/ } 25 \text {; } \\
\text { CR, } 0 / 25 ; \text { PR, I/25; } \\
\text { NO response, } 24 / 25 \text {; } \\
\text { median PFS, } 4.5 \text { months }\end{array}$ \\
\hline Romidepsin & II & $\begin{array}{l}\text { Relapsed or refractory } \\
\text { non-Hodgkin's lymphoma }\end{array}$ & 9 patients & $\begin{array}{l}13 \mathrm{mg} / \mathrm{m}^{2} \text { intravenous injection } \\
\text { over } 4 \text { hours on days I, } 8 \text {, and } 15\end{array}$ & $\begin{array}{l}\text { PR, II.II\%; median PFS, } \\
4 \text { months; median OS, } \\
20 \text { months; no safety issue }\end{array}$ \\
\hline Panobinostat & II & Renal cell carcinoma & 20 patients & 45 mg/day, twice weekly & $\begin{array}{l}\text { Median PFS, I.7 months; } \\
\text { SAEs, 6/30; no safety issue }\end{array}$ \\
\hline Belinostat & II & $\begin{array}{l}\text { Thymoma, thymic } \\
\text { carcinoma }\end{array}$ & 41 patients & $\begin{array}{l}1000 \text { mg daily; } 5 \text { days every } \\
3 \text { weeks }\end{array}$ & $\begin{array}{l}\mathrm{PR}, 2 / 25 \text { thymoma } \\
\text { patients; } 0 / 16 \text { thymic } \\
\text { patients; SAEs, 6/4I }\end{array}$ \\
\hline \multicolumn{6}{|c|}{ Combination therapies } \\
\hline $\begin{array}{l}\text { Vorinostat/ } \\
\text { bexarotene }\end{array}$ & I & $\begin{array}{l}\text { Advanced cutaneous T-cell } \\
\text { lymphoma }\end{array}$ & $\begin{array}{l}6 \text { cohorts } \\
23 \text { patients } \\
\text { total }\end{array}$ & $\begin{array}{l}\text { Vorinostat } 200-400 \mathrm{mg} / \text { day, } \\
\text { bexarotene } 150-300 \mathrm{mg} / \text { day orally, } \\
3 \text { times a week }\end{array}$ & $\begin{array}{l}\text { SAES, } 2 / 23 \text {; response } \\
\text { rate, } 4 / 23\end{array}$ \\
\hline $\begin{array}{l}\text { Vorinostat/ } \\
\text { tamoxifen }\end{array}$ & $\|$ & Breast cancer & 43 patients & $\begin{array}{l}\text { Vorinostat } 400 \mathrm{mg} / \text { day } / 3 \text { out of } \\
4 \text { weeks, tamoxifen } 20 \mathrm{mg} \text { daily }\end{array}$ & $\begin{array}{l}\text { OR, 8/43; TTP, } \\
\text { I0.3 months; SAEs, } 4 / 43 \text {; } \\
\text { safety issue, yes }\end{array}$ \\
\hline $\begin{array}{l}\text { Vorinostat/ } \\
\text { bortezomib }\end{array}$ & I & $\begin{array}{l}\text { Advanced multiple } \\
\text { myeloma }\end{array}$ & $\begin{array}{l}6 \text { cohorts } \\
34 \text { patients } \\
\text { total }\end{array}$ & $\begin{array}{l}\text { Vorinostat } 200-400 \mathrm{mg} / 2 \text { capsules } \\
\text { daily/2I-day cycles, bortezomib } \\
0.7-1.3 \mathrm{mg} / 4 \text { injections per } \\
21 \text {-day cycle }\end{array}$ & $\begin{array}{l}3 \text { discontinued due } \\
\text { to SAEs }\end{array}$ \\
\hline $\begin{array}{l}\text { Vorinostat/ } \\
\text { erlotinib }\end{array}$ & $\mathrm{I} / \mathrm{II}$ & $\begin{array}{l}\text { Relapsed/refractory non- } \\
\text { small-cell lung cancer }\end{array}$ & $\begin{array}{l}2 \text { cohorts } \\
16 \text { patients } \\
\text { total }\end{array}$ & $\begin{array}{l}\text { Vorinostat } 200 \mathrm{mg} / \text { day } / 3 \text { days } \\
\text { per week, erlotinib } 150 \mathrm{mg} / \text { day }\end{array}$ & $\begin{array}{l}\text { SAEs, 5/I6; discontinued } \\
\text { due to progressive } \\
\text { disease, } 9 / 16 \text {; terminated } \\
\text { due to lack of efficacy } \\
\text { and overall tolerance } \\
\text { in patients }\end{array}$ \\
\hline $\begin{array}{l}\text { Vorinostat/ } \\
\text { pemetrexed } \\
\text { and cisplatin }\end{array}$ & I & Advanced solid cancers & $\begin{array}{l}4 \text { cohorts } \\
52 \text { total patients }\end{array}$ & $\begin{array}{l}\text { Vorinostat } 200-400 \mathrm{mg} / \mathrm{l} \text { or } \\
2 \text { capsules daily/ } 14 \text { days out of } \\
3 \text { weeks, pemetrexed }+ \text { cisplatin } \\
\text { or pemetrexed }\end{array}$ & $\begin{array}{l}\text { SAEs, } 20 / 54 \text { patients; } \\
\text { progressive disease, } \\
24 / 54 \text { patients; safety and } \\
\text { tolerability, } 24 / 52 \text { patients }\end{array}$ \\
\hline $\begin{array}{l}\text { Vorinostat/ } \\
\text { decitabine }\end{array}$ & I & $\begin{array}{l}\text { Leukemia, myelocytic, acute } \\
\text { myelodysplastic syndromes }\end{array}$ & $\begin{array}{l}6 \text { cohorts } \\
\text { 7I patients total }\end{array}$ & $\begin{array}{l}\text { Vorinostat } 400 \mathrm{mg} / \text { daily/3 days } \\
\text { out of } 2 \mathrm{I} \text {-day cycle, decitabine } \\
20 \mathrm{mg} \text { daily, } 5 \text { days out of } 28 \text {-day cycle }\end{array}$ & $\begin{array}{l}\text { SAEs, I5/7I; lack of } \\
\text { efficacy, 6/7I; progressive } \\
\text { disease, } 42 / 7 \mid\end{array}$ \\
\hline $\begin{array}{l}\text { Vorinostat/ } \\
\text { trastuzumab }\end{array}$ & $\mathrm{I} / \mathrm{II}$ & Breast cancer & 16 patients & $\begin{array}{l}\text { Vorinostat } 200 \mathrm{mg} \text { twice daily/ } \\
\text { I4 days out of } 2 \mathrm{I} \text {-day cycle, } \\
\text { trastuzumab } 6 \mathrm{mg} / \mathrm{kg} \text { daily, I day } \\
\text { out of } 2 \mathrm{I} \text {-day cycle }\end{array}$ & $\begin{array}{l}\text { Response rate, } 0 / 10 \\
\text { TTP, I.5 months; } \\
\text { SAEs, } 4 / 16\end{array}$ \\
\hline
\end{tabular}

Abbreviations: PR, partial response; PFS, progression-free survival; OS, overall survival; OR, objective response; TTP, time to progression; SAEs, serious adverse effects.

to determine whether VPA increases temozolomide bioavailability or sensitizes for radiochemotherapy due to its HDAC-inhibition properties. ${ }^{94}$

\section{Novel HDAC inhibitors}

Other than those mentioned earlier, some of the more recent HDACIs that have been tested include abexinostat, givinostat, and mocetinostat. Abexinostat (PCI-24781; formerly CRA-024781) is a broad-spectrum phenyl hydroxamate. Preclinical studies involving combination with radiotherapy have suggested it may act in DNA-repair mechanisms, leading to apoptosis. ${ }^{57,95}$ In a phase I clinical study involving refractory advanced solid tumors, patients were relatively successful, with adverse side effects including 
anemia, thrombocytopenia, diarrhea, nausea, vomiting, and fatigue. ${ }^{96}$ Givinostat (ITF2357) is a synthetic HDACI containing a hydroxamic acid moiety linked to an aromatic ring. Both in vitro and in vivo studies involving human tumor cell lines have shown ITF2357 - used either alone or in combination with other agents - has cytotoxic effects and inhibitory effects on proinflammatory cytokines. ${ }^{97,98}$ In a phase II open-label nonrandomized clinical study involving heavily pretreated, relapsed, or refractory Hodgkin's lymphoma patients, preliminary data showed that the oral application of ITF2375 had antitumor activity with an acceptable safety profile. The toxicity profile included grade 1 leukopenia in $30 \%$, grade 2 thrombocytopenia in $33 \%$, fatigue in $50 \%$, grade 1 diarrhea in $40 \%$, and cardiac QT persistence leading to drug discontinuation in $20 \%$ of treated patients. ${ }^{99}$ Mocetinostat (MGCD0103) is a novel HDACI that has strong isotype selectivity to HDAC1 and some weak inhibition to HDAC2, -3 , and -11 . Studies have found MGCD0103 regulates aberrant gene expression and controls tumorigenic growth in malignancies. ${ }^{100}$ Phase I and II clinical trials included treatment of advanced solid tumors, relapsed or refractory acute or chronic myeloid leukemia, myelodysplastic syndrome, acute lymphocytic leukemia, diffuse large B-cell lymphoma, follicular lymphoma, and Hodgkin's lymphoma. MGCD0103 was well tolerated and had antileukemia activity, with side effects consisting mainly of fatigue, nausea, vomiting, and dehydration. ${ }^{101-104}$ A phase I/II trial with MGCD0103 alone or in combination with gemcitabine was performed in patients with solid tumors recently. Preclinical studies found the combination therapy to be more effective than using MGCD0103 alone. ${ }^{105}$

In summary, extensive cell-based assays and clinical studies with HDACIs have been shown to reduce proliferation, induce cell death and apoptosis, cause cell-cycle arrest, and prevent differentiation and migration selectively in malignant and transformed cells with little effect in normal cells. ${ }^{19,51,106}$ This provides them with an advantageous stand-alone therapeutic window in oncology. In addition to their intrinsic cytotoxic properties when tested as a single treatment, HDACIs have been shown to induce additive cytotoxic effects when used in combination with conventional anticancer therapies, such as chemotherapy (anthracyclines and retinoic acid) and radiotherapy. ${ }^{9,19,51,107-112}$ Furthermore, studies with HDACIs in combination with ultraviolet radiation and potent iodinated DNA minor groove-binding ligands have been shown to augment photosensitization and cytotoxicity in tumor cells. ${ }^{113,114}$

\section{Efficacy and safety issues with the use of HDAC inhibitors}

Currently, within clinical trials, the overall response rate of patients to HDACIs has been promising, with generally approximately $30 \%$ patient success. However, the outcomes from long-term case studies have yet to be reported. There has also been little indication whether class-specific HDACIs such as MS-275 or panspecific HDACIs such as vorinostat have been more successful. The toxicity profiles of HDACIs can be compared between the different types, with side effects mainly consisting of diarrhea, myelosuppression and cardiac QT persistence. Most HDACIs have a half-life of 2-8 hours in plasma and will undergo hepatic metabolization and subsequent intestinal excretions. ${ }^{80,102,115-118}$

Furthermore, the use of HDACIs in nononcological models, such as heart disease including cardiac hypertrophy and myocardial ischemia/reperfusion, has been investigated with the therapeutic potential remaining controversial. ${ }^{119-121}$ Investigations from our laboratory aiming to explore the combinatorial effects of the broad-spectrum HDACI trichostatin A with chemotherapy using the anthracycline doxorubicin to induce hypertrophy in rat cardiac myocytes also suggested detrimental effects caused by the HDACI. ${ }^{122,123}$ We reported that trichostatin A augmented doxorubicin-induced hypertrophy by altering the expression of hypertrophyassociated genes. ${ }^{122}$ In addition, further investigations indicated that pretreatment but not posttreatment of cardiac myocytes exposed to trichostatin A and the short-chain fatty acids, VPA, and sodium butyrate augmented DNA damage induced by doxorubicin. ${ }^{122-124}$ It has been proposed that the uncertainty around the therapeutic potential of HDACIs in heart disease stems from the disparate actions of class I and II HDACs. ${ }^{125-128}$ Given the differential findings and the disparity of the actions of the HDACs, particularly in the heart, it is suggested that using isotype- or class-specific HDACIs over broad-spectrum inhibitors may be more successful in this regard.

\section{Conclusion}

HDACIs are a promising new group of anticancer agents that have shown positive responses in preclinical and clinical trials. HDACIs have been shown to induce malignant cell death over a large range of solid and hematological malignancies, with generally normal cell resistance. The mechanism of action of HDACIs requires further precise investigations, and normal cell resistance is not understood. However, this will provide an advantageous therapeutic potential over current conventional oncological modalities, 
which display adverse side effects in normal cells. Furthermore, HDACIs display their biological effects across multiple pathways within the malignant cell, including extrinsic and intrinsic apoptosis, autophagy, inhibiting proliferation, migration, and tumor angiogenesis and effects in the immune response. The fact the normal cells are relatively resistant combined with the multiple defects induced in cancer cells has allowed for relatively high tolerance within clinical investigations. Although clinical trials have been promising, a proportion of patients appear to be unresponsive to HDACI therapy. Accumulating evidence suggests that HDACI therapy may be more successful in combination with other targeted anticancer agents. To date, a range of structurally different inhibitors has been developed that broadly inhibits several HDACs. By developing HDACIs and increasing our understanding of their target HDAC enzymes as well as the effects of targeted inhibitors, we will foster anticancer modalities that are safer and more effective over the current nontargeted agents and current conventional oncological modalities. This will also provide justification for the use of HDACIs as potential therapies for nononcological applications, where we can gain fewer off-target effects by targeting effective biological pathways and processes to reverse or inhibit disease states.

\section{Acknowledgments}

The support of the Australian Institute of Nuclear Science and Engineering is acknowledged. TCK was the recipient of AINSE awards. The Epigenomic Medicine Laboratory is supported by the Australian Research Council Future Fellowship and McCord Research. The Allergy and Immune Disorders Laboratory is supported by MCRI, and PVL is the recipient of an Australian National Health and Medical Research Council training fellowship. Both laboratories are supported in part by the Victorian government's Operational Infrastructure Support Program.

\section{Disclosure}

The authors report no conflicts of interest in this work.

\section{References}

1. Kornberg RD. Chromatin structure: a repeating unit of histones and DNA. Science. 1974;184(4139):868-871.

2. Kornberg RD. Structure of chromatin. Annu Rev Biochem. 1977;46: 931-954.

3. Morrison AJ, Shen X. Chromatin remodelling beyond transcription: the INO80 and SWR1 complexes. Nat Rev Mol Cell Biol. 2009;10(6):373-384.

4. Kouzarides T. Chromatin modifications and their function. Cell. 2007; 128(4):693-705.
5. Jenuwein T, Allis CD. Translating the histone code. Science. 2001; 293(5532):1074-1080.

6. Smith BC, Denu JM. Chemical mechanisms of histone lysine and arginine modifications. Biochim Biophys Acta. 2009;1789(1):45-57.

7. Bernstein BE, Meissner A, Lander ES. The mammalian epigenome. Cell. 2007;128(4):669-681.

8. Roth SY, Denu JM, Allis CD. Histone acetyltransferases. Annu Rev Biochem. 2001;70:81-120.

9. Minucci S, Pelicci PG. Histone deacetylase inhibitors and the promise of epigenetic (and more) treatments for cancer. Nat Rev Cancer. 2006;6(1):38-51.

10. Sanchez R, Zhou MM. The role of human bromodomains in chromatin biology and gene transcription. Curr Opin Drug Discov Devel. 2009;12(5):659-665.

11. Izzo A, Schneider R. Chatting histone modifications in mammals. Brief Funct Genomics. 2010;9(5-6):429-443.

12. Duan H, Heckman CA, Boxer LM. Histone deacetylase inhibitors downregulate bcl-2 expression and induce apoptosis in $\mathrm{t}(14 ; 18)$ lymphomas. Mol Cell Biol. 2005;25(5):1608-1619.

13. Rada-Iglesias A, Enroth S, Ameur A, et al. Butyrate mediates decrease of histone acetylation centered on transcription start sites and down-regulation of associated genes. Genome Res. 2007;17(6): 708-719.

14. de Ruijter AJ, van Gennip AH, Caron HN, Kemp S, van Kuilenburg AB. Histone deacetylases (HDACs): characterization of the classical HDAC family. Biochem J. 2003;370(Pt 3):737-749.

15. Gregoretti IV, Lee YM, Goodson HV. Molecular evolution of the histone deacetylase family: functional implications of phylogenetic analysis. J Mol Biol. 2004;338(1):17-31.

16. Yang XJ, Seto E. The Rpd3/Hda1 family of lysine deacetylases: from bacteria and yeast to mice and men. Nat Rev Mol Cell Biol. 2008;9(3): 206-218.

17. Tanner KG, Landry J, Sternglanz R, Denu JM. Silent information regulator 2 family of NAD-dependent histone/protein deacetylases generates a unique product, 1-O-acetyl-ADP-ribose. Proc Natl Acad Sci US A. 2000;97(26):14178-14182.

18. Martin M, Kettmann R, Dequiedt F. Class IIa histone deacetylases: regulating the regulators. Oncogene. 2007;26(37):5450-5467.

19. Marks PA. Histone deacetylase inhibitors: a chemical genetics approach to understanding cellular functions. Biochim Biophys Acta. 2010;1799(10-12):717-725.

20. Ocker M. Deacetylase inhibitors - focus on non-histone targets and effects. World J Biol Chem. 2010;1(5):55-61.

21. Glozak MA, Sengupta N, Zhang X, Seto E. Acetylation and deacetylation of non-histone proteins. Gene. 2005;363:15-23.

22. Spange S, Wagner T, Heinzel T, Krämer OH. Acetylation of non-histone proteins modulates cellular signalling at multiple levels. Int J Biochem Cell Biol. 2009;41(1):185-198.

23. Cress WD, Seto E. Histone deacetylases, transcriptional control, and cancer. J Cell Physiol. 2000;184(1):1-16.

24. Ocker M, Schneider-Stock R. Histone deacetylase inhibitors: signalling towards p21cip1/waf1. Int J Biochem Cell Biol. 2007;39(7-8): 1367-1374.

25. Fraga MF, Ballestar E, Villar-Garea A, et al. Loss of acetylation at Lys 16 and trimethylation at Lys 20 of histone $\mathrm{H} 4$ is a common hallmark of human cancer. Nat Genet. 2005;37(4):391-400.

26. Choi JH, Kwon HJ, Yoon BI, et al. Expression profile of histone deacetylase 1 in gastric cancer tissues. Jpn J Cancer Res. 2001;92(12): 1300-1304.

27. Halkidou K, Gaughan L, Cook S, Leung HY, Neal DE, Robson CN. Upregulation and nuclear recruitment of HDAC1 in hormone refractory prostate cancer. Prostate. 2004;59(2):177-189.

28. Zhang Z, Yamashita H, Toyama T, et al. HDAC6 expression is correlated with better survival in breast cancer. Clin Cancer Res. 2004;10(20): 6962-6968.

29. Zhang Z, Yamashita H, Toyama T, et al. Quantitation of HDAC1 mRNA expression in invasive carcinoma of the breast. Breast Cancer Res Treat. 2005;94(1):11-16. 
30. Zhu P, Martin E, Mengwasser J, Schlag P, Janssen KP, Göttlicher M. Induction of HDAC2 expression upon loss of APC in colorectal tumorigenesis. Cancer Cell. 2004;5(5):455-463.

31. Wilson AJ, Byun DS, Popova N, et al. Histone deacetylase 3 (HDAC3) and other class I HDACs regulate colon cell maturation and p21 expression and are deregulated in human colon cancer. J Biol Chem. 2006;281(19):13548-13558.

32. Lagger G, O'Carroll D, Rembold M, et al. Essential function of histone deacetylase 1 in proliferation control and $\mathrm{CDK}$ inhibitor repression. EMBO J. 2002;21(11):2672-2681.

33. Montgomery RL, Davis CA, Potthoff MJ, et al. Histone deacetylases 1 and 2 redundantly regulate cardiac morphogenesis, growth, and contractility. Genes Dev. 2007;21(14):1790-1802.

34. Montgomery RL, Potthoff MJ, Haberland M, et al. Maintenance of cardiac energy metabolism by histone deacetylase 3 in mice. $J$ Clin Invest. 2008;118(11):3588-3597.

35. Vega RB, Matsuda K, Oh J, et al. Histone deacetylase 4 controls chondrocyte hypertrophy during skeletogenesis. Cell. 2004;119(4): $555-566$

36. Chang S, Young BD, Li S, Qi X, Richardson JA, Olson EN. Histone deacetylase 7 maintains vascular integrity by repressing matrix metalloproteinase 10. Cell. 2006;126(2):321-334.

37. Chang S, McKinsey TA, Zhang CL, Richardson JA, Hill JA, Olson EN. Histone deacetylases 5 and 9 govern responsiveness of the heart to a subset of stress signals and play redundant roles in heart development. Mol Cell Biol. 2004;24(19):8467-8476.

38. Haberland M, Mokalled MH, Montgomery RL, Olson EN. Epigenetic control of skull morphogenesis by histone deacetylase 8. Genes Dev. 2009;23(14):1625-1630.

39. Lin RJ, Sternsdorf T, Tini M, Evans RM. Transcriptional regulation in acute promyelocytic leukemia. Oncogene. 2001;20(49): 7204-7215.

40. Marks PA, Breslow R. Dimethyl sulfoxide to vorinostat: development of this histone deacetylase inhibitor as an anticancer drug. Nat Biotechnol. 2007;25(1):84-90.

41. Campas-Moya C. Romidepsin for the treatment of cutaneous T-cell lymphoma. Drugs Today (Barc). 2009;45(11):787-795.

42. Prince HM, Bishton MJ, Harrison SJ. Clinical studies of histone deacetylase inhibitors. Clin Cancer Res. 2009;15(12):3958-3969.

43. Lane AA, Chabner BA. Histone deacetylase inhibitors in cancer therapy. J Clin Oncol. 2009;27(32):5459-5468.

44. Marks PA. The clinical development of histone deacetylase inhibitors as targeted anticancer drugs. Expert Opin Investig Drugs. 2010;19(9): 1049-1066.

45. Schneider-Stock R, Ocker M. Epigenetic therapy in cancer: molecular background and clinical development of histone deacetylase and DNA methyltransferase inhibitors. IDrugs. 2007;10(8):557-561.

46. Hu E, Dul E, Sung CM, et al. Identification of novel isoform-selective inhibitors within class I histone deacetylases. J Pharmacol Exp Ther. 2003;307(2):720-8.

47. Parmigiani RB, Xu WS, Venta-Perez G, et al. HDAC6 is a specific deacetylase of peroxiredoxins and is involved in redox regulation. Proc Natl Acad Sci U S A. 2008;105(28):9633-9638.

48. Haggarty SJ, Koeller KM, Wong JC, Grozinger CM, Schreiber SL. Domain-selective small-molecule inhibitor of histone deacetylase 6 (HDAC6)-mediated tubulin deacetylation. Proc Natl Acad Sci U S A. 2003;100(8):4389-4394.

49. Namdar M, Perez G, Ngo L, Marks PA. Selective inhibition of histone deacetylase 6 (HDAC6) induces DNA damage and sensitizes transformed cells to anticancer agents. Proc Natl Acad Sci U SA. 2010; 107(46):20003-20008.

50. Tang W, Luo T, Greenberg EF, Bradner JE, Schreiber SL. Discovery of histone deacetylase 8 selective inhibitors. Bioorg Med Chem Lett. 2011;21(9):2601-2605.

51. Marks PA, Xu WS. Histone deacetylase inhibitors: potential in cancer therapy. J Cell Biochem. 2009;107(4):600-608.
52. Richon VM, SandhoffTW, Rifkind RA, Marks PA. Histone deacetylase inhibitor selectively induces p21WAF1 expression and geneassociated histone acetylation. Proc Natl Acad Sci U S A. 2000;97(18): 10014-10019.

53. Sandor V, SenderowiczA, Mertins S, et al. P21-dependent g(1)arrest with downregulation of cyclin D1 and upregulation of cyclin E by the histone deacetylase inhibitor FR901228. Br J Cancer. 2000;83(6):817-825.

54. Zhao Y, Tan J, Zhuang L, Jiang X, Liu ET, Yu Q. Inhibitors of histone deacetylases target the Rb-E2F1 pathway for apoptosis induction through activation of proapoptotic protein Bim. Proc Natl Acad Sci $U S$ A. 2005;102(44):16090-16095.

55. Harikrishnan KN, Karagiannis TC, Chow MZ, El-Osta A. Effect of valproic acid on radiation-induced DNA damage in euchromatic and heterochromatic compartments. Cell Cycle. 2008;7(4):468-476.

56. Karagiannis TC, El-Osta A. Chromatin modifications and DNA double-strand breaks: the current state of play. Leukemia. 2007;21(2): 195-200.

57. Adimoolam S, Sirisawad M, Chen J, Thiemann P, Ford JM, Buggy JJ. HDAC inhibitor PCI-24781 decreases RAD51 expression and inhibits homologous recombination. Proc Natl Acad Sci U S A. 2007;104(49):19482-19487.

58. Zhang Y, Carr T, Dimtchev A, Zaer N, Dritschilo A, Jung M. Attenuated DNA damage repair by trichostatin A through BRCA1 suppression. Radiat Res. 2007;168(1):115-124.

59. Hotchkiss RS, Strasser A, McDunn JE, Swanson PE. Cell death. NEngl J Med. 2009;361(16):1570-1583.

60. Bolden JE, Peart MJ, Johnstone RW. Anticancer activities of histone deacetylase inhibitors. Nat Rev Drug Discov. 2006;5(9):769-784.

61. Srivastava RK, Kurzrock R, Shankar S. MS-275 sensitizes TRAIL-resistant breast cancer cells, inhibits angiogenesis and metastasis, and reverses epithelial-mesenchymal transition in vivo. Mol Cancer Ther. 2010;9(12):3254-3266.

62. Rikiishi H. Autophagic and apoptotic effects of HDAC inhibitors on cancer cells. J Biomed Biotechnol. 2011;2011:830260.

63. Zhang Y, Adachi M, Kawamura R, Imai K. Bmf is a possible mediator in histone deacetylase inhibitors FK228 and CBHA-induced apoptosis. Cell Death Differ. 2006;13(1):129-140.

64. Xu Y. Regulation of $\mathrm{p} 53$ responses by post-translational modifications. Cell Death Differ. 2003;10(4):400-403.

65. Ma X, Ezzeldin HH, Diasio RB. Histone deacetylase inhibitors: current status and overview of recent clinical trials. Drugs. 2009;69(14):1911-1934.

66. Adams RH, Alitalo K. Molecular regulation of angiogenesis and lymphangiogenesis. Nat Rev Mol Cell Biol. 2007;8(6): 464-478.

67. Lin EY, Pollard JW. Tumor-associated macrophages press the angiogenic switch in breast cancer. Cancer Res. 2007;67(11):5064-5066.

68. Kim MS, Kwon HJ, Lee YM, et al. Histone deacetylases induce angiogenesis by negative regulation of tumor suppressor genes. Nat Med. 2001;7(4):437-443.

69. Fath DM, Kong X, Liang D, et al. Histone deacetylase inhibitors repress the transactivation potential of hypoxia-inducible factors independently of direct acetylation of HIF-alpha. J Biol Chem. 2006;281(19): $13612-13619$.

70. Kong X, Lin Z, Liang D, Fath D, Sang N, Caro J. Histone deacetylase inhibitors induce VHL and ubiquitin-independent proteasomal degradation of hypoxia-inducible factor 1alpha. Mol Cell Biol. 2006;26(6):2019-2028.

71. Duvic M, Talpur R, Ni X, et al. Phase 2 trial of oral vorinostat (suberoylanilide hydroxamic acid SAHA) for refractory cutaneous T-cell lymphoma (CTCL). Blood. 2007;109(1):31-39.

72. Olsen EA, Kim YH, Kuzel TM, et al. Phase IIb multicenter trial of vorinostat in patients with persistent progressive or treatment refractory cutaneous T-cell lymphoma. J Clin Oncol. 2007;25(21):3109-3115.

73. Khan O, La Thangue NB. Drug insight: histone deacetylase inhibitor-based therapies for cutaneous T-cell lymphomas. Nat Clin Pract Oncol. 2008;5(12):714-726. 
74. Kirschbaum M, Frankel P, Popplewell L, et al. Phase II study of vorinostat for treatment of relapsed or refractory indolent non-Hodgkin's lymphoma and mantle cell lymphoma. J Clin Oncol. 2011;29(9): $1198-1203$.

75. Luu TH, Morgan RJ, Leong L, et al. A phase II trial of vorinostat (suberoylanilide hydroxamic acid) in metastatic breast cancer: a California Cancer Consortium study. Clin Cancer Res. 2008;14(21): 7138-7142.

76. Traynor AM, Dubey S, Eickhoff JC, et al. Vorinostat (NSC\# 701852) in patients with relapsed non-small cell lung cancer: a Wisconsin Oncology Network phase II study. J Thorac Oncol. 2009;4(4):522-526.

77. Vansteenkiste J, Van Cutsem E, Dumez H, et al. Early phase II trial of oral vorinostat in relapsed or refractory breast colorectal or non-small cell lung cancer. Invest New Drugs. 2008;26(5):483-488.

78. Blumenschein GR Jr, Kies MS, Papadimitrakopoulou VA, et al. Phase II trial of the histone deacetylase inhibitor vorinostat (Zolinza, suberoylanilide hydroxamic acid SAHA) in patients with recurrent and/or metastatic head and neck cancer. Invest New Drugs. 2008;26(1):81-87.

79. Modesitt SC, Sill M, Hoffman JS, Bender DP. A phase II study of vorinostat in the treatment of persistent or recurrent epithelial ovarian or primary peritoneal carcinoma: a Gynecologic Oncology Group study. Gynecol Oncol. 2008;109(2):182-186.

80. Sandor V, Bakke S, Robey RW, et al. Phase I trial of the histone deacetylase inhibitor depsipeptide (FR901228 NSC 630176) in patients with refractory neoplasms. Clin Cancer Res. 2002;8(3):718-728.

81. Marshall JL, Rizvi N, Kauh J, et al. A phase I trial of depsipeptide (FR901228) in patients with advanced cancer. $J$ Exp Ther Oncol. 2002;2(6):325-332.

82. Stadler WM, Margolin K, Ferber S, McCulloch W, Thompson JA. A phase II study of depsipeptide in refractory metastatic renal cell cancer. Clin Genitourin Cancer. 2006;5(1):57-60.

83. Byrd JC, Marcucci G, Parthun MR, et al. A phase 1 and pharmacodynamic study of depsipeptide (FK228) in chronic lymphocytic leukemia and acute myeloid leukemia. Blood. 2005;105(3):959-967.

84. Klimek VM, Fircanis S, Maslak P, et al. Tolerability pharmacodynamics and pharmacokinetics studies of depsipeptide (romidepsin) in patients with acute myelogenous leukemia or advanced myelodysplastic syndromes. Clin Cancer Res. 2008;14(3):826-832.

85. Schrump DS, Fischette MR, Nguyen DM, et al. Clinical and molecular responses in lung cancer patients receiving romidepsin. Clin Cancer Res. 2008;14(1):188-198.

86. Kummar S, Gutierrez M, Gardner ER, et al. Phase I trial of MS-275, a histone deacetylase inhibitor, administered weekly in refractory solid tumors and lymphoid malignancies. Clin Cancer Res. 2007;13(18 Pt 1): 5411-5417.

87. Gore L, Rothenberg ML, O'Bryant CL, et al. A phase I and pharmacokinetic study of the oral histone deacetylase inhibitor, MS-275, in patients with refractory solid tumors and lymphomas. Clin Cancer Res. 2008;14(14):4517-4525.

88. Gojo I, Jiemjit A, Trepel JB, et al. Phase 1 and pharmacologic study of MS-275, a histone deacetylase inhibitor, in adults with refractory and relapsed acute leukemias. Blood. 2007;109(7):2781-2790.

89. Blum W, Klisovic RB, Hackanson B, et al. Phase I study of decitabine alone or in combination with valproic acid in acute myeloid leukemia. J Clin Oncol. 2007;25(25):3884-3891.

90. Soriano AO, Yang H, Faderl S, et al. Safety and clinical activity of the combination of 5-azacytidine, valproic acid, and all-trans retinoic acid in acute myeloid leukemia and myelodysplastic syndrome. Blood. 2007;110(7):2302-2308.

91. Atmaca A, Al-Batran SE, Maurer A, et al. Valproic acid (VPA) in patients with refractory advanced cancer: a dose escalating phase I clinical trial. Br J Cancer. 2007;97(2):177-182.

92. Münster P, Marchion D, Bicaku E, et al. Phase I trial of histone deacetylase inhibition by valproic acid followed by the topoisomerase II inhibitor epirubicin in advanced solid tumors: a clinical and translational study. J Clin Oncol. 2007;25(15):1979-1985.
93. Candelaria M, Gallardo-Rincón D, Arce C, et al. A phase II study of epigenetic therapy with hydralazine and magnesium valproate to overcome chemotherapy resistance in refractory solid tumors. Ann Oncol. 2007;18(9):1529-1538.

94. Weller M, Gorlia T, Cairncross JG, et al. Prolonged survival with valproic acid use in the EORTC/NCIC temozolomide trial for glioblastoma. Neurology. 2011;77(12):1156-1164.

95. Banuelos CA, Banáth JP, MacPhail SH, Zhao J, Reitsema T, Olive PL. Radiosensitization by the histone deacetylase inhibitor PCI-24781. Clin Cancer Res. 2007;13(22 Pt 1):6816-6826.

96. Undevia S, Janisch L, Schilsky RL, et al. Phase I study of the safety, pharmacokinetics (PK) and pharmacodynamics (PD) of the histone deacetylase inhibitor (HDACi) PCI-24781. J Clin Oncol. 2008; 26 Suppl:14514.

97. Barbetti V, Gozzini A, Rovida E, et al. Selective anti-leukaemic activity of low-dose histone deacetylase inhibitor ITF2357 on AML1/ETOpositive cells. Oncogene. 2008;27(12):1767-1778.

98. Guerini V, Barbui V, Spinelli O, et al. The histone deacetylase inhibitor ITF2357 selectively targets cells bearing mutated JAK2(V617F). Leukemia. 2008;22(4):740-747.

99. Viviani S, Bonfante V, Fasola C, Valagussa P, Gianni AM. Phase II study of the histone-deacetylase inhibitor ITF2357 in relasped/refractory Hodgkin's lymphoma patients. J Clin Oncol. 2008;26 Suppl:8532.

100. Le Tourneau C, Siu LL. Promising antitumor activity with MGCD0103, a novel isotype-selective histone deacetylase inhibitor. Expert Opin Investig Drugs. 2008;17(8):1247-1254.

101. Siu LL, Pili R, Duran I, et al. Phase I study of MGCD0103 given as a three-times-per-week oral dose in patients with advanced solid tumors. J Clin Oncol. 2008;26(12):1940-1947.

102. Garcia-Manero G, Assouline S, Cortes J, et al. Phase 1 study of the oral isotype specific histone deacetylase inhibitor MGCD0103 in leukemia. Blood. 2008;112(4):981-989.

103. Crump M, Andreadis C, Assouline S, et al. Treatment of relapsed or refractory non-hodgkin lymphoma with the oral isotype-selective histone deacetylase inhibitor MGCD0103: Interim results from a phase II study. J Clin Oncol. 2008;26 Suppl:8528.

104. Bociek RG, Kuruvilla J, Pro B, et al. Isotype-selective histone deacetylase (HDAC) inhibitor MGCD0103 demonstrates clinical activity and safety in patients with relapsed/refractory classical Hodgkin lymphoma (HL). J Clin Oncol. 2008;26 Suppl:8507.

105. Hurwitz H, Nelson B, O'Dwyer PJ, et al. Phase I/II: The oral isotype-selective HDAC inhibitor MGCD0103 in combination with gemcitabine (Gem) in patients (pts) with refractory solid tumors. JClin Oncol. 2008;26 Suppl:4625.

106. Kwa FA, Balcerczyk A, Licciardi P, El-Osta A, Karagiannis TC. Chromatin modifying agents - the cutting edge of anticancer therapy. Drug Discov Today. 2011;16(13-14):543-547.

107. De los Santos M, Zambrano A, Sánchez-Pacheco A, Aranda A. Histone deacetylase inhibitors regulate retinoic acid receptor beta expression in neuroblastoma cells by both transcriptional and posttranscriptional mechanisms. Mol Endocrinol. 2007;21(10):2416-2426.

108. De los Santos M, Zambrano A, Aranda A. Combined effects of retinoic acid and histone deacetylase inhibitors on human neuroblastoma SH-SY5Y cells. Mol Cancer Ther. 2007;6(4):1425-1432.

109. Kim HJ, Bae SC. Histone deacetylase inhibitors: molecular mechanisms of action and clinical trials as anti-cancer drugs. Am J Transl Res. 2011;3(2):166-179.

110. Karagiannis TC, Harikrishnan KN, El-Osta A. Disparity of histone deacetylase inhibition on repair of radiation-induced DNA damage on euchromatin and constitutive heterochromatin compartments. Oncogene. 2007;26(27):3963-3971.

111. Karagiannis TC, Harikrishnan KN, El-Osta A. The histone deacetylase inhibitor, trichostatin A, enhances radiation sensitivity and accumulation of gammaH2A.X. Cancer Biol Ther. 2005;4(7):787-793.

112. Sanchez-Gonzalez B, Yang H, Bueso-Ramos C, et al. Antileukemia activity of the combination of an anthracycline with a histone deacetylase inhibitor. Blood. 2006;108(4):1174-1182. 
113. Briggs B, Ververis K, Rodd AL, Foong LJ, Silva FM, Karagiannis TC. Photosensitization by iodinated DNA minor groove binding ligands: evaluation of DNA double-strand break induction and repair. J Photochem Photobiol B. 2011;103(2):145-152.

114. Singh TR, Shankar S, Srivastava RK. HDAC inhibitors enhance the apoptosis-inducing potential of TRAIL in breast carcinoma. Oncogene. 2005;24(29):4609-4623.

115. Kelly WK, O'Connor OA, Krug LM, et al. Phase I study of an oral histone deacetylase inhibitor suberoylanilide hydroxamic acid in patients with advanced cancer. J Clin Oncol. 2005;23(17):3923-3931.

116. Rubin EH, Agrawal NG, Friedman EJ, et al. A study to determine the effects of food and multiple dosing on the pharmacokinetics of vorinostat given orally to patients with advanced cancer. Clin Cancer Res. 2006;12(23):7039-7045.

117. Garcia-Manero G, Yang H, Bueso-Ramos C, et al. Phase 1 study of the histone deacetylase inhibitor vorinostat (suberoylanilide hydroxamic acid [SAHA]) in patients with advanced leukemias and myelodysplastic syndromes. Blood. 2008;111(3):1060-1066.

118. Lech-Maranda E, Robak E, Korycka A, Robak T. Depsipeptide (FK228) as a novel histone deacetylase inhibitor: mechanism of action and anticancer activity. Mini Rev Med Chem. 2007;7(10):1062-1069.

119. Cao DJ, Wang ZV, Battiprolu PK, et al. Histone deacetylase (HDAC) inhibitors attenuate cardiac hypertrophy by suppressing autophagy. Proc Natl Acad Sci U S A. 2011;108(10):4123-4128.

120. Cho YK, Eom GH, Kee HJ, et al. Sodium valproate, a histone deacetylase inhibitor, but not captopril, prevents right ventricular hypertrophy in rats. Circ J. 2010;74(4):760-770.

121. Bogaard HJ, Mizuno S, Hussaini AA, et al. Suppression of histone deacetylases worsens right ventricular dysfunction after pulmonary artery banding in rats. Am J Respir Crit Care Med. 2011;183(10): 1402-1410.

122. Karagiannis TC, Lin AJ, Ververis K, et al. Trichostatin A accentuates doxorubicin-induced hypertrophy in cardiac myocytes. Aging (Albany N Y). 2010;2(10):659-668.

123. Ververis K, Rodd AL, Tang MM, El-Osta A, Karagiannis TC. Histone deacetylase inhibitors augment doxorubicin-induced DNA damage in cardiomyocytes. Cell Mol Life Sci. 2011;68(24):4101-4114.

124. Ververis K, Karagiannis TC. Potential non-oncological applications of histone deacetylase inhibitors. Am J Transl Res. 2011;3(5):454-467.

125. McKinsey TA, Olson EN. Dual roles of histone deacetylases in the control of cardiac growth. Novartis Found Symp. 2004;259:132-141; discussion 141-145, 163-169.

126. Backs J, Olson EN. Control of cardiac growth by histone acetylation/ deacetylation. Circ Res. 2006;98(1):15-24.

127. Haberland M, Montgomery RL, Olson EN. The many roles of histone deacetylases in development and physiology: implications for disease and therapy. Nat Rev Genet. 2009;10(1):32-42.

128. Zhang CL, McKinsey TA, Chang S, Antos CL, Hill JA, Olson EN. Class II histone deacetylases act as signal-responsive repressors of cardiac hypertrophy. Cell. 2002;110(4):479-488.

129. Gu W, Roeder RG. Activation of $\mathrm{p} 53$ sequence-specific DNA binding by acetylation of the p53 C-terminal domain. Cell. 1997;90(4):595-606.

130. Thevenet L, Méjean C, Moniot B, et al. Regulation of human SRY subcellular distribution by its acetylation/deacetylation. EMBO J. 2004;23(16):3336-3345.

131. Yuan ZL, Guan YJ, Chatterjee D, Chin YE. Stat3 dimerization regulated by reversible acetylation of a single lysine residue. Science. 2005;307(5707):269-273.

132. Boyes J, Byfield P, Nakatani Y, Ogryzko V. Regulation of activity of the transcription factor GATA-1 by acetylation. Nature. 1998;396(6711):594-598.

133. Hayakawa F, Towatari M, Ozawa Y, Tomita A, Privalsky ML, Saito H. Functional regulation of GATA-2 by acetylation. $J$ Leukoc Biol. 2004;75(3):529-540.

134. Martínez-Balbás MA, Bauer UM, Nielsen SJ, Brehm A, Kouzarides T. Regulation of E2F1 activity by acetylation. EMBO J. 2000;19(4):662-671.
135. Sartorelli V, Puri PL, Hamamori Y, et al. Acetylation of MyoD directed by PCAF is necessary for the execution of the muscle program. Mol Cell. 1999;4(5):725-734.

136. Yao YL, Yang WM, Seto E. Regulation of transcription factor YY1 by acetylation and deacetylation. Mol Cell Biol. 2001;21(17):5979-5991.

137. Munshi N, Merika M, Yie J, Senger K, Chen G, Thanos D. Acetylation of HMG I(Y) by CBP turns off IFN beta expression by disrupting the enhanceosome. Mol Cell. 1998;2(4):457-467.

138. Lührs H, Hock R, Schauber J, et al. Modulation of HMG-N2 binding to chromatin by butyrate-induced acetylation in human colon adenocarcinoma cells. Int J Cancer. 2002;97(5):567-573.

139. Kiernan R, Brès V, Ng RW, et al. Post-activation turn-off of NF-kappa B-dependent transcription is regulated by acetylation of p65. J Biol Chem. 2003;278(4):2758-2766.

140. Luo J, Li M, Tang Y, Laszkowska M, Roeder RG, Gu W. Acetylation of p53 augments its site-specific DNA binding both in vitro and in vivo. Proc Natl Acad Sci U SA. 2004;101(8):2259-2264.

141. Munshi N, Agalioti T, Lomvardas S, Merika M, Chen G, Thanos D. Coordination of a transcriptional switch by HMGI(Y) acetylation. Science. 2001;293(5532):1133-1136.

142. Wang R, Cherukuri P, Luo J. Activation of Stat3 sequence-specific DNA binding and transcription by p300/CREB-binding protein-mediated acetylation. J Biol Chem. 2005;280(12):11528-11534.

143. Fu M, Wang C, Reutens AT, et al. P300 and p300/cAMP-response element-binding protein-associated factor acetylate the androgen receptor at sites governing hormone-dependent transactivation. J Biol Chem. 2000;275(27):20853-20860.

144. Gaughan L, Logan IR, Cook S, Neal DE, Robson CN. Tip60 and histone deacetylase 1 regulate androgen receptor activity through changes to the acetylation status of the receptor. $J$ Biol Chem. 2002;277(29):25904-29513.

145. Wang $\mathrm{C}, \mathrm{Fu} \mathrm{M}$, Angeletti RH, et al. Direct acetylation of the estrogen receptor alpha hinge region by $\mathrm{p} 300$ regulates transactivation and hormone sensitivity. J Biol Chem. 2001;276(21): 18375-18383.

146. Yamagata T, Mitani K, Oda H, et al. Acetylation of GATA-3 affects T-cell survival and homing to secondary lymphoid organs. EMBO J. 2000;19(17):4676-4687.

147. Zhang W, Bieker JJ. Acetylation and modulation of erythroid Krüppellike factor (EKLF) activity by interaction with histone acetyltransferases. Proc Natl Acad Sci U S A. 1998;95(17):9855-9860.

148. Marzio G, Wagener C, Gutierrez MI, Cartwright P, Helin K, Giacca M. E2F family members are differentially regulated by reversible acetylation. J Biol Chem. 2000;275(15):10887-10892.

149. Jin $\mathrm{YH}$, Jeon EJ, Li QL, et al. Transforming growth factor-beta stimulates p300-dependent RUNX3 acetylation which inhibits ubiquitination-mediated degradation. J Biol Chem. 2004;279(28): 29409-29417.

150. Jeong JW, Bae MK, Ahn MY, et al. Regulation and destabilization of HIF-1alpha by ARD1-mediated acetylation. Cell. 2002;111(5): 709-720.

151. Ito A, Kawaguchi Y, Lai CH, et al. MDM2-HDAC1-mediated deacetylation of p53 is required for its degradation. EMBO J. 2002;21(22):6236-6245

152. Patel JH, Du Y, Ard PG, et al. The c-MYC oncoprotein is a substrate of the acetyltransferases hGCN5/PCAF and TIP60. Mol Cell Biol. 2004;24(24):10826-10834.

153. Gaughan L, Logan IR, Neal DE, Robson CN. Regulation of androgen receptor and histone deacetylase 1 by Mdm2-mediated ubiquitylation. Nucleic Acids Res. 2005;33(1):13-26.

154. Kawai H, Li H, Avraham S, Jiang S, Avraham HK. Overexpression of histone deacetylase HDAC1 modulates breast cancer progression by negative regulation of estrogen receptor alpha. Int $J$ Cancer. 2003;107(3):353-358.

155. Grönroos E, Hellman U, Heldin CH, Ericsson J. Control of Smad7 stability by competition between acetylation and ubiquitination. Mol Cell. 2002;10(3):483-493. 
156. Fu M, Wang C, Wang J, et al. Androgen receptor acetylation governs trans activation and MEKK1-induced apoptosis without affecting in vitro sumoylation and trans-repression function. Mol Cell Biol. 2002;22(10):3373-3388.

157. Zhang W, Kadam S, Emerson BM, Bieker JJ. Site-specific acetylation by $\mathrm{p} 300$ or CREB binding protein regulates erythroid Krüppel-like factor transcriptional activity via its interaction with the SWI-SNF complex. Mol Cell Biol. 2001;21(7): 2413-2422.

158. Bannister AJ, Miska EA, Görlich D, Kouzarides T. Acetylation of importin-alpha nuclear import factors by CBP/p300. Curr Biol. 2000;10(8):467-470.
159. Chen LF, Fischle W, Verdin E, Greene WC. Duration of nuclear NF-kappaB action regulated by reversible acetylation. Science. 2001;293(5535):1653-1657.

160. Cohen HY, Lavu S, Bitterman KJ, et al. Acetylation of the C terminus of Ku70 by CBP and PCAF controls Bax-mediated apoptosis. Mol Cell. 2004;13(5):627-638.

161. Kovacs JJ, Murphy PJ, Gaillard S, et al. HDAC6 regulates Hsp90 acetylation and chaperone-dependent activation of glucocorticoid receptor. Mol Cell. 2005;18(5):601-607.

\section{Publish your work in this journal}

Biologics: Targets \& Therapy is an international, peer-reviewed journal focusing on the patho-physiological rationale for and clinical application of Biologic agents in the management of autoimmune diseases, cancers or other pathologies where a molecular target can be identified. This journal is indexed on PubMed Central, CAS, EMBase, Scopus

\section{Dovepress}

and the Elsevier Bibliographic databases. The manuscript management system is completely online and includes a very quick and fair peerreview system, which is all easy to use. Visit http://www.dovepress com/testimonials.php to read real quotes from published authors. 